交通騒音に対する住民意識と沿道植栽地の 心理的効果に関する研究

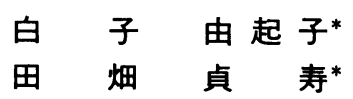

Consciousness of People, Mental Effects of Road Side Planting Space and Traffic Noise.

Yukiko SHIRAKO

Sadatoshi TABATA

\begin{abstract}
摘要：交通騒音の被害を受けている沿道住民の意識調查と公内での心理垁験を行うことにより, 沿道植栽地の心理 的効果について検討を試みた。その結果, 緑視率 $50 \%$ の沿道植栽地では線 $2 \mathrm{~dB}(\mathrm{~A})$, 緑視率 $93 \%$ では約 $5 \mathrm{~dB}(\mathrm{~A})$ の 効果量を得た。この約 $5 \mathrm{~dB}$ (A)の効果量とは, 住民意識調査の結果から住民の 4 割が文通騒音に対する心理的効果を 認める数值でもあることが示された。
\end{abstract}

1. はじめに

近年交通騒音に対しての諸研究は，さまざまな側面か ら多くの研究例が見られる。これらのうち, 本研究に関 連する研究としては, (1)沿道植栽地を造成するてとによ り，騒音の減衰を図ろうとした研究，G. O. ロビネッテ $1^{1)}$, 建設省土木研究所 ${ }^{2)}$ や，(2)減音効果としての緑（緑 地, 樹林, 樹木, 生垣, 森林など) があつ物理的効果に ついての研究, 例えば本多3), 高橋4), 三沢5), 鹿島ら ${ }^{6)}$ が ある。また(3)緑の心理的効果からの減音については，建 設省土木研究所の研究7广などが稀 の研究についての実験方法は, 実態調查による方法8)ゃ S D法, 調整法, 極限法などがある。緑の量と騒音感と の関係については, 緑量を 5 段階に分けて実験している が, その結果，ヒトは 5 段階といった細かな緑量の違い は区別できず， 2 段階程度の大まかな緑量の違いが区別 できるという報告がみられる 路環境の意識調查では, 防音機能について地域差がある こと ${ }^{10)}$, 騒音に対する不満度は道路からの距離之関係が

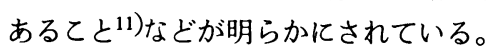

本研究では既応の研究を踏まえつつ, 居住環境亡交通 騒音,ならびに沿道植栽地などの緑地施設の騒音緩和効 果について基礎的な諸資料を得ることを目的に実施した。 まずはじめに交通騒音と緑効果について意識調查を行っ た。次に交通騒音に対する沿道植栽地の心理的効果につ いてビデオを用いた調整法 (method of adjustment) による実験を行い, 住民意識と実験から得られた各種デ ータの関係について考察した。

この研究報告のうち白子は意識調查及び心理実験につ

*千葉大学園芸学部造園施設学研究室
いて具体的に作業を実施し, まとめた。田畑は意識調查 法と心理実験の関係について考察を加えた。また, 三沢 氏 (千葉大環境緑地学科助教授) には終始実験方法につ いて指導を受けた。

\section{2. 研究の内容と方法}

(1)研究対象地区の選定と理由

本研究は交通騒音と住民意識及び治道植栽地の効果に ついて心理的側面から捉えようとするものである。従っ て，(1)交通量がある程度多く，また一定であること。(2)道 路周辺に居住者がいること。(3)沿道に植栽地があり, そ れが異なった概観を呈しているてと。の 3 点を考慮して 東京都の環状 7 号線之東京都及び千葉県内の国道 6 号線 沿いの表- 1 研究対象地一覧に示す 5 ケ所を対象地とし て選定した。(1)国道 6 号線治いの葛飾区金町 2 丁目は全 く植栽の存在しない所で, 下記 4 ケ所の対照地として選 した。(2)心理実験では世田谷区若林 $2 丁$ 目, 意識調查で は若林 1 丁目, 2 丁目， 5 丁目の環 7 通り中央より偪約 $100 \mathrm{~m}$, 延長約 $300 \mathrm{~m}$ の地区である。乙の治道には, 約

\section{表一1 研究対象地一筧}

\begin{tabular}{|c|c|c|c|c|}
\hline \multirow{2}{*}{ 地区番号 } & \multirow{2}{*}{ 対 象 地 区 } & \multicolumn{2}{|c|}{ 呈示順* } & \multirow{2}{*}{$\begin{array}{c}\text { 緑視率 } \\
(\%)\end{array}$} \\
\hline & & (1) $\rightarrow$ & $\rightarrow$ (1) & \\
\hline (1) & 䓪飾区金町 2-7 & $/$ & / & 0 \\
\hline (2) & 世田谷区若林 2-16 & 1 & 4 & 50 \\
\hline (3) & 練馬区豊玉中 2-16 & 5 & 8 & 79 \\
\hline (4) & 練馬区豊玉南 2-25 & 6 & 3 & 93 \\
\hline (5) & 千枼県柏市豊町 $2-5$ & 2 & 7 & 100 \\
\hline
\end{tabular}

(1) $\rightarrow \square$ は金町地区を基準として各地区を評定する場合

$\square \rightarrow$ (1) は各地区を基準として金町地区を評定する場合 
$5 \mathrm{~m}$ 間隔で樹高 $4.2 \mathrm{~m}$ のウバメガシが, 低木にオオムラ サキが植栽されている。(3)環 7 通りに面した練馬区豊玉 中 2 丁目地区は，樹高約 $10.0 \mathrm{~m}$ のケヤキ,クスノキが約 $3 \mathrm{~m}$ 間隔で植えられ, その間に樹高 $2.0 \mathrm{~m}$ のサンゴジュ が 1 本ずつ植栽されている。(4)意識調查は練馬区豊玉南 2 丁目, 豊玉中 2 丁目、 3 丁目の環 7 通り中央より幅約 $100 \mathrm{~m}$, 延長約 $650 \mathrm{~m}$ の地区であり, 心理実験はてのう ち豊玉南 2 丁目である。樹高 $1.8 \mathrm{~m}$ のサンゴジュが生垣 状に配され，約 $10 \mathrm{~m}$ 間隔で樹高 5.5〜6.0 mのトウカエ デ，低木にはオオムラサキが植栽されている。(5)国道 6 号線沿いの千葉県柏市豊町 2 丁目, 樹高約 $2.0 \mathrm{~m}$ のサワ ラが車道が見えないほど密に植栽されている。以上 5 ケ 所の対象地区に面する幹線道路は，すべて片側 2 車線と なっている。意識調査においては，(2)及び(4)を，心理実 験に扔いては(1)〜(5)をそれぞれ対象地とした。また(2)， (4)において幅を $100 \mathrm{~m}$ としたのは，騒音は幹線道路から の距䧸の影響が大きく，交通量の多い地区では40〜 $80 \mathrm{~m}$ まで道路の影響がみられる12) という報告に基づくもので ある。

\section{(2)意識調查の内容と方法}

若林地区と豊玉南地区に扔て, 各地区の居住環境と 交通騒音の関係，騒音と定住意識について，また交通騒 音に対する沿道植栽地の物理的，心理的効果などについ て，住民の意識を把握するととを目的に実施した。主な 調査項目は，(1)交通騒音，振動，ほてり・空気の污れを はじめとする居住環境に対する困笨度, (2)定住希望につ いて，また転居希望者に対しては，その理由，(3)沿道植 栽地の認識度, (4)沿道植栽地の心理的効果の有無, (5)住 民の属性について，などである。調査は1984年 9 月 24 日 〜29日にかけて留置法で行い, 回収率を考慮して住民に 調査用紙を直接手渡す方法をとった。そして 3 日後に回 収したが，その結果，若林地区は配布数 365 , 回収数 149 , よって回収率 $40.8 \%$ であった。また, 豊玉南地区は配布 数 350 , 回収数 137 , 回収率 $39.1 \%$ であった。回収した 調査用紙は単純集計した後，クロス集計を行い，その結 果を $1 / 1500$ 住宅地図（ゼンリン）上にプロットする方 法で作業を進めた。なお，両地区とも男女ほぼ同数の回 答数が得られ, 年齢別にみた回収率は, 表一 2 年齢別回 収率に示す通りで，30代以上の人がほとんどである。

\section{表一2 年齢別回収率}

\begin{tabular}{|c|r|r|r|r|r|r|r|r|}
\hline 年齢 & $10 \sim$ 地区名 $^{20}$ & 20 & $30 \sim$ & $40 \sim$ & $50 \sim$ & $60 \sim$ & 不明 & 計 \\
\hline 若林地区 & 0 & 17 & 28 & 20 & 17 & 14 & 4 & 100 \\
\hline 豊玉南地区 & 1 & 7 & 23 & 20 & 20 & 18 & 11 & 100 \\
\hline
\end{tabular}

(3)心理実験の内容と方法

本実験は前項の意識調查を踏まえた上で，上記の対象

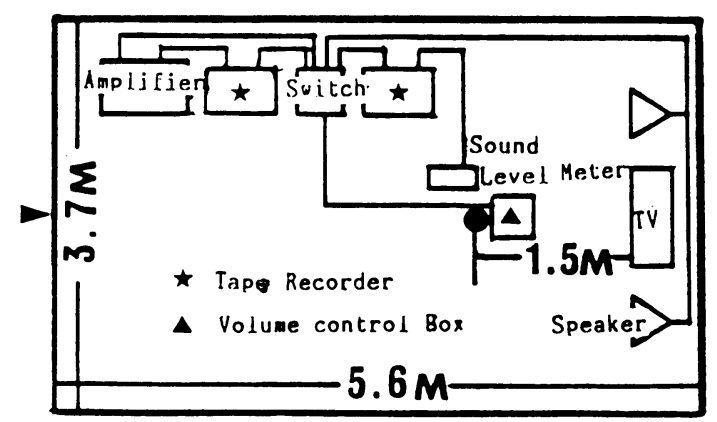

図-1 実験室内配置図

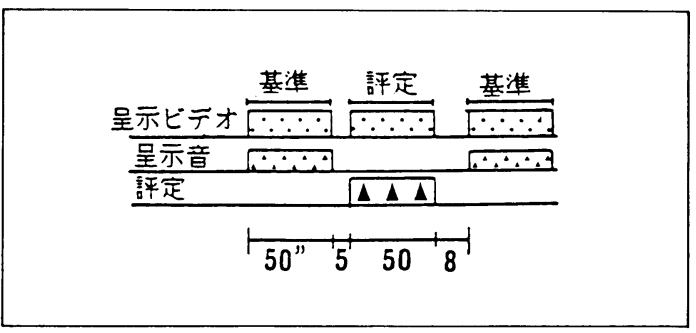

図一2 実験の進行

地区 5 ケ所について, 沿道植栽地が心理的に交通騒音を 緩和する効果をむつととを明らかにし，沿道植栽地の緑 視率の違いによる心理的効果を検討するものである。1 実験日時・場所・被験者：1984年10月19～26日，千葉大 学造溒施設学研究室 (困- 1 参照), 被験者は千葉大学学 生55名（内女性18名）19 30才である。(2実験の進行: ビデオと音を50秒間呈示する。乙れを，それぞれ基準ビ デオ，基準音とよぶてととする。 5 秒の間隔をおいてビ デオだけが50秒間呈示される。乙れを評定ビデオとよび， このビデオを見ながら評定を行う。評定方法は, 先の基 準ビデオには基準音がふさわしいと想定した場合に，評 定ビデオにふさわしい音の大きさを騒音レベル $0 \mathrm{~dB}(\mathrm{~A})$ の状態から調整していくものである。被験者が調整した 騒音レベルを評定音とよぶ。 8 秒の間隔をおいてまた 基準音と基準ビデオを呈示するというように繰り返す。 てれを模式化したのが図 -2 実験の進行である。はじめ に練習と音の再現性の検証を兼稀て，金町地区を基準と 評定の両方のビデオに用いて 3 回行い，その後に金町地 区を基準として評定ビデオを若林地区，豊玉中地区，豊 玉南地区, 柏地区の各地区とする順之, 逆に後者 4 地区 を基準として前者金町地区を評定ビデオとする順の 2 通 りについてアトランダムに呈示した。呈示順は前記の表 - 1 に示す通りである。基準音及び評定音はすべてテー プに録音した後, 記録紙上に記述されたグラフから数値 を読みとった。(3実験装置：基準音及び評定音は，自動 車騒音とホワイトノイズとでは実験結果に差がない13) ことからノイズフィールドゼネレーター（RION, SF 造闺雑誌 $48(5), 1985$ 
-02型）による音をテープに録音し，それをテープレコ 一ダ（SONY, TC - 5550-2）で再生し, アンプ（テ クニクス，SU-V-8X)で增幅し，被験者前方 $1.5 \mathrm{~m}$ に 置かれているスピーカ（テクニクス, SB-M 5) から呈 示する。基準音及び評定音は，被験者の耳の高さ（休上 $1 \mathrm{~m}$ ）に三脚で固定された精密騒音計(RION, NA-60) を通じて $A$ 特性でテープレコーダ（同上）に録音し，後 で高速度レベルレコーダ（RION，LA-03）により記録 紙上に記述した。その他, 被験者の手元にはボタン操作 の音量調整器があり, 実験者側には実験者と被験者の音 量切換えスイッチがある。なお，基準音の騒音レベルは 約77. $4 \mathrm{~dB}$ (A) である。呈示画面については，現実に近 い状態を表わすためにビデオを採用した。車道端より 2.5 $\mathrm{m}$, 高さ $1.2 \mathrm{~m}$ の歩道上にビデオカメラを設置し，道路 と直角の方向で10秒，それを中心に周辺の概況を知るた めに左右に60度カメラをまわし，それぞれ60度の地点で 5 秒ずつ停止した後，また正面にむいて10秒となるビデ オフィルムを作製した。そのビデオを被験者前方 $1.5 \mathrm{~m}$ の位置にある20インチカラーテレビ（ビクター, AV$\mathrm{S}$-20）より呈示する。各対象地はビデオでの撮影と同 時に,カラーフィルムでの撮影む行った。その写真とビ デオの画面とは，ほぼ一致しているととを確認した後，

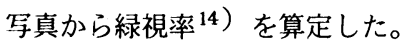

\section{3. 研究の結果と考察}

\section{(1)意識調查の結果と考察}

(i ) 居住環境亡交通騒音の関係

居住環境の要因別にその困窎度の高い項目はほこり・ 空気の污れが若林地区で52\%, 豊玉南地区で57\%, 交通 騒音が若林地区で $41 \%$ ，豊玉南地区で53\%，災害に対す る危険性が前者で $46 \%$, 後者で $43 \%$ となっており, 交通 騒音む両地区においては大きな問題となっているととが わかる。

交通騒音について「困っている」と「困っていない」 の 2 種に分類し, 両地区について地図上にプロットした のが図-3交通騒音で困っている人の分布である。ての 図からわかることは, 道路敷から $20 \mathrm{~m}$ 毎に区切られた中 で道路際 $20 \mathrm{~m}$ ないし $40 \mathrm{~m} て ゙$ 困っていると感じている人が 圧倒的に多く分布していることである。また交通騒音は 発生する道路からの距離と深い関係がみられる。

(ii)騒音と定住意識

定住意識について,「定住希望」,「転居希望」,「不明」 の 3 項目より選択した結果と居住歴との関係をみると, 両地区とも居住歴 10 年以上の人が半数以上を占めている 豊玉南地区においては，32\%の人が定住希望で，そのう ちの大半が 10 年以上の居住歴をむつ人である。また $37 \%$ の人が転居を希望しているが, 居住歴とはあまり関係が ない。一方若林地区をみると，4割の人が転居を希望し
ており, 居住歴 10 年以上の人がその半数を占めている。 定住希望の大半は豊玉南地区之同様, 10 年以上居住して いる人である。両地区を比較してみると, 豊玉南地区は 定住及び転居希望の割合がほぼ同程度であるのに対して， 若林地区では転居希望の割合が大きいことと，両地区と あ定住希望の人は 10 年以上の居住歴をもつ人に多いこと がわかる。

転居を希望する人の中で，その理由に「騒音などで環 境が悪いから」をあげた人を特に抜き出し，若林地区に ついて地図上にプロットしたのが, 図一4転居希望の分 布図である。騒音などで環境が悪いととを理由に転居を 希望する人は，他の理由によって転居を希望する人に比 べて, 若林地区の道路東側を除いた両地区の道路から 20 $\mathrm{m}$ 以内で顕著である。若林地区の道路東側は $60 \mathrm{~m}$ まで転

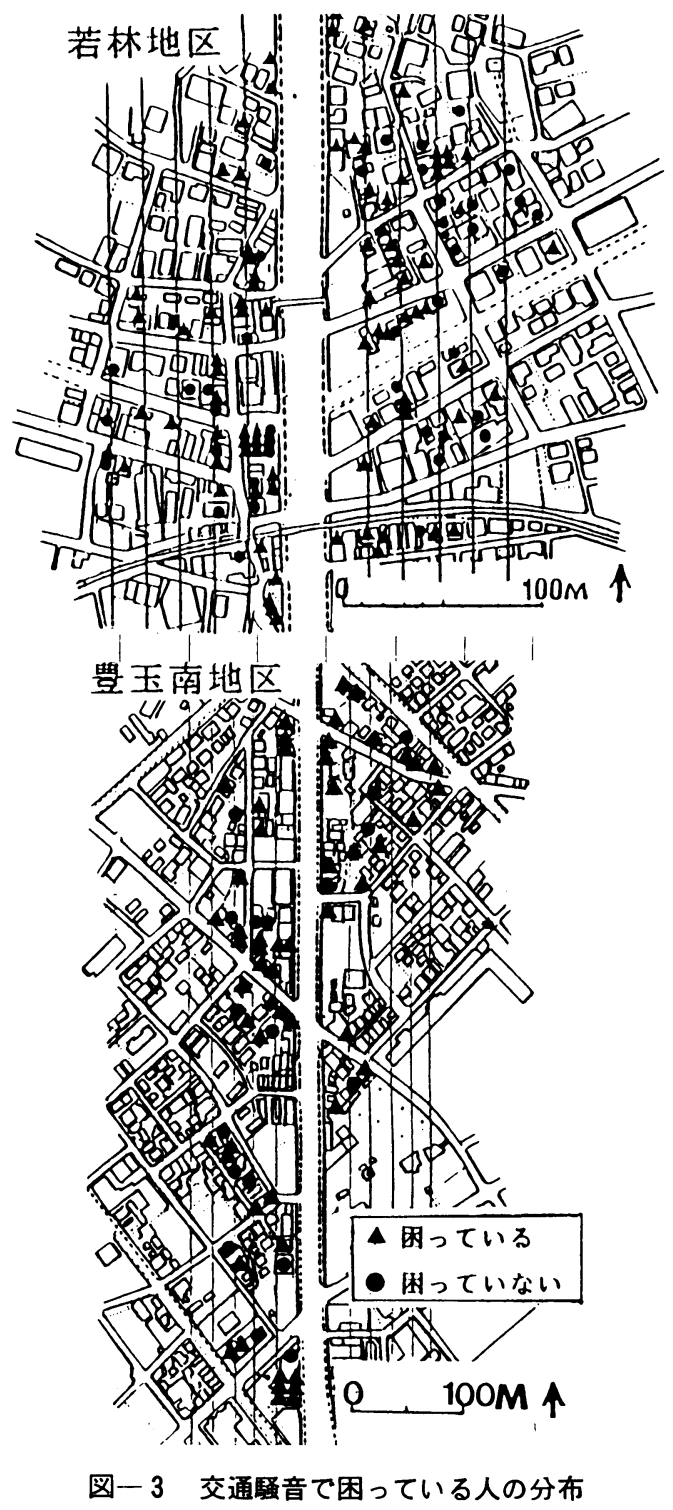




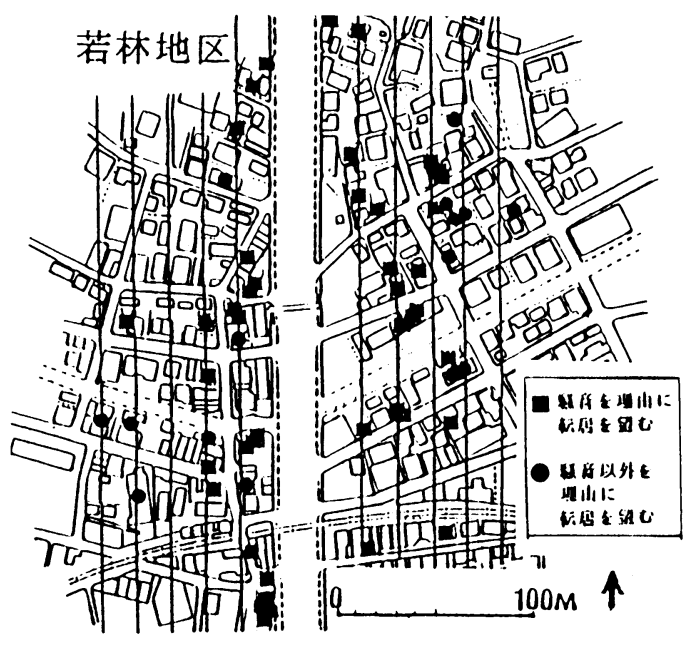

図一４転居希望の分布図

居理由に騒音をあげている。てれと交通騒音で困ってい る人とを両地区について戸別に比べてみると，日頃騒音 に悩んでいる人が転居を望む場合，騒音をその理由と するケースが多く，他の理由をあげる人は稀である。 よって，交通騒音は転居の理由になるなど，大きい問題 として住民がとらえていると考えられる。また定住を希 望する割合は，道路から離れるにしたブって増加してい く傾向がうかがえる。

(iii)交通騒音に対する沿道植栽地の効果について,

「あなたの家の近くの環状 7 号線には, 街路樹があり ますか」という質問に対する結果は表一 3 各地区におけ る街路樹の認識度に示す通りである。若林地区で73\%， 豊玉南地区で $91 \%$ の人が「街路樹がある」と答えており, 「街路樹がない」或いは「わからない」と答えた人は前 者で $20 \%$ ，後者で $6 \%$ を占めている。このととから両地 区とも大方の人は街路樹即ち沿道植栽地について認識し ているが，豊玉南地区の方が若林地区に比べて認識度は 高いといえる。乙れは沿道植栽地の緑量の違いによる差 ではないかと考えられる。即ち，若林地区では低木が植 栽されているとてろに $5 \mathrm{~m}$ 間隔で高木が見える程度であ るのに対して, 豊玉南地区では中木が生垣状に植栽され ているため, その緑量感から認識度屯高くなっていると いえよう。また街路樹があると答えた人とそうでない人 の分布をみてみると、特偏りがあるわけでなく，一様 に分布しているてとから，道路から $100 \mathrm{~m}$ 範囲に押い ては, 沿道植栽地の認識は, 植栽地からの距離とは関係 がないといえる。

交通騒音に対する沿道植栽地の心理的効果，即ち「街 路樹があるてとによって交通騒音が, 気分的に静かに感 じる」と答えた人は，表一 4 交通騒音に対する沿道植栽 地の物理的，心理的効果に示すように若林地区では $15 \%$ ， 豊玉南地区では40\%となっている。「心理的効果がない」
表一3 各地区における街路樹の認識度

\begin{tabular}{|c|c|c|}
\hline 項目 地区名 & 若林地区 & 豊玉南地区 \\
\hline 街路樹がある & $73 \%$ & $91 \%$ \\
\hline 街路樹がない & 14 & 3 \\
\hline 不 & 6 & 3 \\
\hline 他 & 7 & 3 \\
\hline 計 & $100 \%$ & $100 \%$ \\
\hline
\end{tabular}

表一4 交通騷音に対する沿道植栽地の物理的， 心理的効果

\begin{tabular}{|c|c|c|c|}
\hline 物理的 & \multirow{2}{*}{$\begin{array}{c}\text { 心理的 } \\
\text { 効 }\end{array}$} & \multicolumn{2}{c|}{ 地 } \\
\cline { 4 - 4 } 効 & 果 & 名 \\
\hline 若林地区 & 豊玉南地区 \\
\hline 有 & 有 & $4 \%$ & $21 \%$ \\
\hline 有 & 無 & 2 & 14 \\
\hline 無 & 有 & 11 & 19 \\
\hline 無 & 無 & 83 & 46 \\
\hline \multicolumn{2}{|c|}{ 計 } & $100 \%$ & $100 \%$ \\
\hline
\end{tabular}

と答えた人は，前者で $85 \%$ ，後者で60\%である。また心 理的効果のみならず，物理的効果も考え合わせてみると 「物理的効果がある」と答えた人は若林地区で $6 \%$ ，豊 玉南地区で35\%である。物理的効果む心理的効果もない と感じている人は，若林地区では $83 \%$ 高く, 豊玉南地 区では46\%である。逆に，物理的及び心理的効果の両方 を認めている人は，若林地区で $4 \%$ \%あるのに対し，豊 玉南地区では21\%を占めている。乙のような物理的或い は心理的効果の地区による違いは, 街路樹の認識度にも みられるように，沿道植栽地の緑量の違いによるあので あると考えられる。また豊玉南地区のような生垣状の植 栽形態と若林地区の植栽形態を比較してみると, 音源で ある自動車の見え方は植栽の存在によって影響を受けて いることがわかる。そこで次に緑視率の違いによる沿道 植栽地の心理的効果について実験を行った。

(2)心理実験の結果と考察

(i 緑視率の測定結果

緑視率の測定については，心理実験の内容と方法の項 で既に述べた通りで，その結果については表-1 研究対 象地一覧に示す通りである。

(ii)基準音と評定音の測定結果からみた交通騒音に対す る心理的効果

植栽のない地区を基準として植栽のある地区を評定す る実験を B S 実験, 逆に, 植栽のある地区を基準として 植栽のない地区を評定する実験を S B 実験とよぶことと する。もしあ B S 実験に扔いて評定音一基準音の差がマ イナスであったなら, 被験者は植栽のない方をうるさく 感じ，植栽のある方を植栽けない方に比べて静かだと評 価したてとになる。よって，心理的効果が認められたと いえよう。S B 実験ではてれと逆に，評定者一基準音の 差がプラスであれば, 心理的効果が認められたといえる。

実験により得られた測定結果のうち，意識調查を行っ 
表一 5 地区別分散比と平均値の推定

\begin{tabular}{|c|c|c|c|c|c|}
\hline 項目 & 地区名 & 若林地区 & 豊玉中地区 & 豊玉南地区 & 柏 地 区 \\
\hline & 比 & $37 . \quad 37 * *$ & $95.00 \% *$ & $143 . \quad 11 * *$ & $233.86 * *$ \\
\hline 平均値 & B S 実験 & $-3.47 \sim-1.59$ & $-5.20 \sim-3.04$ & $-6.29 \sim-4.16$ & $-13.97 \sim-10.14$ \\
\hline の推定 & S B実験 & $-0.39 \sim 1.44$ & $0.46 \sim 2.60$ & $0.49 \sim 2.56$ & $1.75 \sim 5.54$ \\
\hline
\end{tabular}

**は有意水準 $1 \%$ で有意, 平均値の推定の単位 : $\mathrm{d} B(\mathrm{~A})$

た豊玉南地区を例にグラフ化したあのが図ー 5 基準音と 評定音の関係である。各地区毎に B S , S B 実験で得ら れた評定音一基準音の差について，P C-9801を用いて 分散分析した結果，表一 5 地区別分散比之平均值の推定 に示すような分散比が得られた。いずれる有意水準 $1 \%$ で有意である。即ち，B S 実験とS B 実験の間に確かに 差があることがわかった。次に平均値を推定したとてろ， 先の表- 5 地区別分散比と平均値の推定に示す值を得た。 てれは B S 実験及びS B実験の評定音一基準音の差がそ れぞれマイナス側，プラス側に高い確率で分布している かどうかを確かめるものである。その結果, 若林地区で はあまり明確ではないが，その他の地区では明確にマイ ナス側とプラス側に分散していることがわかる。つまり， 植栽があるときは騒音が緩和され，逆に植栽がないとき は騒音が增大される。よって, 沿道植栽地の心理的効果 が認められたといえる。ただし，手順の違いによりB S 実験と S B 実験の平均值に差が表われている。また，基 準と評定に同じ金町地区を使って実験した結果から評定 音と基準音との間に $0.3 \mathrm{~dB}(\mathrm{~A})$ の差がみられた。以上 2 つの結果をもとに, 緑視率の違いによる心理的効果を B S 実験について分散分析を行った結果, 緑視率の分散 比は 61.66 となり, 有意水準 $1 \%$ で有意であった。即ち, 緑視率の違いにより心理的効果の効果量に差があるとと がわかった。緑視率 $0 \%$ の地区とその他の地区との比較

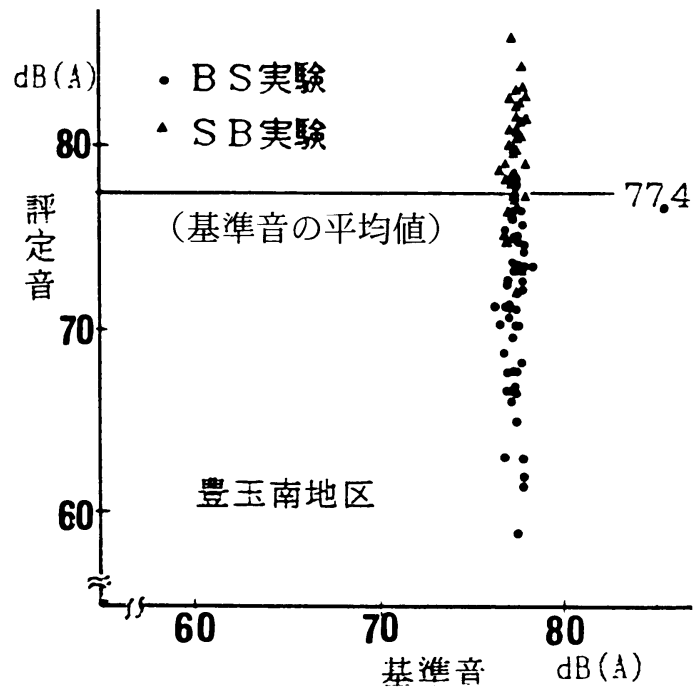

図一 5 基準音と評定音の関係

\section{表一 6 緑視率と心理的効果量}

\begin{tabular}{|c|c|c|}
\hline 地 区 名 & 緑視率 & 心理的効果 量 \\
\hline 若 林 地 区 & $50 \%$ & $0.1 \sim 4.3 \mathrm{~dB}(\mathrm{~A})$ \\
\hline 豊玉中地区 & 79 & $1.7 \sim 5.8 \mathrm{~dB}(\mathrm{~A})$ \\
\hline 豊玉南地区 & 93 & $2.8 \sim 7.0 \mathrm{~dB}(\mathrm{~A})$ \\
\hline 柏 地 区 & 100 & $9.7 \sim 13.8 \mathrm{~dB}(\mathrm{~A})$ \\
\hline
\end{tabular}

を行い, 心理的効果の効果量 ${ }^{15)}$ を求めたところ, 表一 6 緑視率と心理的効果量を得た。乙の表から緑視率が高 い程効果量は大きくなり，緑視率が50９3\%では $0.1 〜 ~$ 7. $0 \mathrm{~dB}(\mathrm{~A})$ )の効果量があるといえる。また, 緑視率 100 \%においては，9.7〜13.8dB (A) という高い値を得た。 (3)意識調查と心理実鸦の結果と考察

若林地区と豊玉南地区の 2 地区について交通騒音や沿 道植栽地に関する意識調查を実施した結果, 沿道植栽地 の認識度及び沿道植栽地の物理的，心理的効果に地区間 の相違が表われている。若林地区は豊玉南地区に比べて 認識度も物理的, 心理的効果む低い。乙れは個人差であ るととも一つの理由ではあろうが，それよりあむしろ沿 道植栽地の緑量の違いによるむのと考えられる。2 地区 の歩道を歩いてみると, 豊玉南地区では植栽地の存在感 が大きいのに対し，若林地区では植栽地を意識すること が少ない。特に豊玉南地区の植栽形態は車道と歩道を明 確に分けていて，実に「緑の壁」といったとてろである。 意識調查の結果から沿道植栽地の緑量の違いを緑視率と 考え, 緑視率之心理的効果について心理実験を行い, 検 証してみた。その結果，沿道植栽地の心理的効果が認め られ, 緑視率の違いによって心理的効果の効果量にあ差 があるととが明らかとなった。とくに意識調査を行った 2 地区に注目してみると，若林地区（緑視率50\%）に おりる効果量は $0.1 \sim 4.3 \mathrm{~dB}(\mathrm{~A})$ であり, 豊玉南地区 (緑視率 $93 \%)$ )では $2.8 〜 7.0 \% \mathrm{~dB}$ (A) という結果を 得た。乙の効果量と意識調査とを考え合わせてみると， $2 \mathrm{~dB}$ (A) 位の効果量では交通騒音に対する沿道植栽地 の心理的効果として $15 \%$ のが認めるにすぎないが， 5 $\mathrm{dB}(\mathrm{A})$ 程の効果量になると $40 \%$ の人がその心理的効果 を認めているということができる。

\section{4. おわりに}

既応研究及び本研究から, 沿道植栽地の心理的効果量 は2 $5 \mathrm{~dB}$ (A) であるといえる。乙れが日常生活にお いて大きな意味をもつか否かは明確にはできないが, 少 
なくとも沿道植栽地には心理的に騒音を緩和する効果が あることは確かである。また既応研究から物理的には 7 $\mathrm{dB}$ 減衰するのに $30 \mathrm{~m}$ の植栽幅が必要だとする研究 16$)$ を はじめ様々な值が示されているが, 物理的効果之心理 的効果が合わさって相乗効果を生むような植栽地を配置 することが望まれる。なお，今後の研究として沿道植栽 地が沿道景観の心理的効果にあつながることや，沿道植 栽地の防じん効果なども含めて，複合的効果について科 学的な研究が進められることが重要と思われる。

最後になりましたが, 本研究を進めるにあたり，岩河 信文部長（建設省建築研究所）に御助言をいただき，乙 こに感謝の意を表します。

\section{補注および文献}

1） G. O. ロビネッティ著, 三沢・山本訳 (1978)：図 説生活環境亡緑の機能：産業技術センター

2）建設省土木研究所（1982）: 道路植栽の環境緩和機 能墽する調查報告書

3 ) 本多俟 (1972)：緑地の防音機能の計量化とその評 価に関する研究：日本造園学会昭和 47 年春季大会発 表要旨

4 ）高橋宏司（1975）：樹木帯による防音効果試験：岐 阜県林業センター 昭和45年度試験研究成果報告

5 ）三沢彰（1978）：植栽の防音効果に関する研究(I) 無響室内における実験一：日本造園学会昭和53年秋
季大会発表要旨

6 ）鹿島教昭・田村明弘（1983）：植樹帯による物理的 減音効果：日本音響学会講演論文集

7 ）建設省土木研究所（1982）：緑の効果の評価に関す る調查 $(2)$

8）社日本公園緑地協会（1984）：地区環境における緑 地系の効果分析に関する調查研究報告書

9 ）建設省土木研究所（1983）：緑の効果の評価に関す る調查報告書

10）三沢彰・伊藤登（1984）：環境施設帯植栽に対する 沿道住民の意識について: 造園雑誌研究発表論文集 2

11）原科幸彦ほか（1981）：住民意識調查にもとづく道 路周辺地域の環境診断 : 第16回日本都市計画学会学 術研究発表会

12）11）に同じ

13）9）に同じ

14）ここでいう緑視率とは，写真に写された植栽地とそ の後方部の関係から画面の緑被部分と非緑被部分と の割合を測定したあのをいう。

15）ここでいう効果量とは，心理実験により得られたデ 一夕をもとに交通騒音が心理的に緩和されると思わ れる数量値のことである。

16）1）に同じ

Summary: Guiding question was, whether road side planting space can mentally ease traffic noise. We made two investigations. Firstly by means of a questionnaire, we inquired the conciousness of residents who lived along side a road and suffered from traffic noise. Secondly, we tried psychological indoor experiment using a video-tape simulating the conditions to ascertain the first investigation. These two data combined show the following results.

The traffic noise was definitely mentally eased by the road side planting space. That depended on the rate of view of green. $50 \%$ corresponded to $2 \mathrm{~dB}(\mathrm{~A})$ and $93 \%$ to $5 \mathrm{~dB}(\mathrm{~A})$. Moreover $5 \mathrm{~dB}$ (A) corresponded to the numerical value at which $40 \%$ of the people could mentally feel an easing of the traffic noise. 